\title{
Appendix
}

\section{A Robustness Results}

\section{A.1 Results with heteroskedasticity-robust standard errors}

Table A.1: Public Servants in 1900 and Type of War Dynamic

\begin{tabular}{|c|c|c|c|c|c|c|}
\hline & \multicolumn{6}{|c|}{ Public Servants per 1,000} \\
\hline & (1) & $(2)$ & $(3)$ & (4) & $(5)$ & (6) \\
\hline Insurgents & $\begin{array}{c}0.155 \\
(0.110)\end{array}$ & $\begin{array}{c}0.047 \\
(0.109)\end{array}$ & $\begin{array}{c}0.083 \\
(0.107)\end{array}$ & $\begin{array}{c}0.170 \\
(0.115)\end{array}$ & $\begin{array}{c}0.017 \\
(0.117)\end{array}$ & $\begin{array}{c}0.065 \\
(0.116)\end{array}$ \\
\hline Local Militias & $\begin{array}{c}0.705^{* * *} \\
(0.243)\end{array}$ & $\begin{array}{c}0.617^{* *} \\
(0.240)\end{array}$ & $\begin{array}{c}0.521^{* *} \\
(0.229)\end{array}$ & $\begin{array}{c}0.698^{* * *} \\
(0.243)\end{array}$ & $\begin{array}{c}0.595^{* *} \\
(0.236)\end{array}$ & $\begin{array}{l}0.519^{* *} \\
(0.228)\end{array}$ \\
\hline Militia recapture & $\begin{array}{c}0.822^{* * *} \\
(0.279)\end{array}$ & $\begin{array}{c}0.689^{* *} \\
(0.280)\end{array}$ & $\begin{array}{c}0.504^{*} \\
(0.274)\end{array}$ & $\begin{array}{c}0.837^{* * *} \\
(0.282)\end{array}$ & $\begin{array}{c}0.758^{* * *} \\
(0.273)\end{array}$ & $\begin{array}{c}0.626^{* *} \\
(0.267)\end{array}$ \\
\hline Soil Suitability $(0,1,2)$ & & $\begin{array}{l}-0.107 \\
(0.083)\end{array}$ & $\begin{array}{l}-0.106 \\
(0.082)\end{array}$ & & $\begin{array}{c}-0.195^{*} \\
(0.117)\end{array}$ & $\begin{array}{l}-0.190 \\
(0.117)\end{array}$ \\
\hline Median altitude $(\mathrm{km})$ & & $\begin{array}{c}-0.097 \\
(0.088)\end{array}$ & $\begin{array}{l}-0.110 \\
(0.087)\end{array}$ & & $\begin{array}{c}-0.195^{* *} \\
(0.088)\end{array}$ & $\begin{array}{c}-0.200^{* *} \\
(0.088)\end{array}$ \\
\hline $1000 \mathrm{~km}$ to closest mine c. 1800 & & $\begin{array}{c}1.365 \\
(1.415)\end{array}$ & $\begin{array}{c}1.183 \\
(1.415)\end{array}$ & & $\begin{array}{c}5.858^{* * *} \\
(1.866)\end{array}$ & $\begin{array}{c}5.675^{* * *} \\
(1.867)\end{array}$ \\
\hline Km to nearest colonial city & & $\begin{array}{c}0.003^{*} \\
(0.002)\end{array}$ & $\begin{array}{c}0.003^{* *} \\
(0.002)\end{array}$ & & $\begin{array}{c}0.002 \\
(0.002)\end{array}$ & $\begin{array}{l}0.004^{*} \\
(0.002)\end{array}$ \\
\hline Km to Mexico City & & $\begin{array}{c}0.001 \\
(0.001)\end{array}$ & $\begin{array}{c}0.001 \\
(0.001)\end{array}$ & & $\begin{array}{l}-0.001 \\
(0.001)\end{array}$ & $\begin{array}{l}-0.001 \\
(0.001)\end{array}$ \\
\hline Customs Office c.1800 $(0,1)$ & & $\begin{array}{c}0.401^{* * *} \\
(0.102)\end{array}$ & & & $\begin{array}{c}0.475^{* * *} \\
(0.112)\end{array}$ & \\
\hline Alcabala collected (1000s) & & & $\begin{array}{c}0.048^{* * *} \\
(0.008)\end{array}$ & & & $\begin{array}{c}0.048^{* * *} \\
(0.008)\end{array}$ \\
\hline Mean dep. var. & 1.138 & 1.138 & 1.138 & 1.198 & 1.198 & 1.198 \\
\hline Municipalities & 2007 & 2007 & 2007 & 1163 & 1163 & 1163 \\
\hline $\mathrm{R}^{2}$ & 0.234 & 0.263 & 0.273 & 0.159 & 0.213 & 0.232 \\
\hline
\end{tabular}

Note: OLS with state fixed effects and robust standard errors; (3) and (4) include only neighbors.

* sig at 10 percent; ${ }^{* *}$ sig at 5 percent; ${ }^{* * *}$ sig at 1 percent.

See the text for a description of the variables and data sources. 
Table A.2: Municipal Budget in 1910 and Type of War Dynamic

\begin{tabular}{lcccccc}
\hline & & \multicolumn{5}{c}{ Municipal Budget per capita 1910} \\
& $(1)$ & $(2)$ & $(3)$ & $(4)$ & $(5)$ & $(6)$ \\
\hline Insurgents & 0.287 & 0.235 & 0.256 & 0.278 & 0.219 & 0.255 \\
& $(0.203)$ & $(0.194)$ & $(0.215)$ & $(0.206)$ & $(0.196)$ & $(0.224)$ \\
Local Militias & $0.473^{* * *}$ & $0.357^{* *}$ & $0.237^{* *}$ & $0.458^{* * *}$ & $0.335^{* *}$ & $0.252^{* *}$ \\
& $(0.153)$ & $(0.149)$ & $(0.119)$ & $(0.153)$ & $(0.150)$ & $(0.124)$ \\
Militia recapture & $0.906^{* * *}$ & $0.774^{* *}$ & $0.578^{*}$ & $0.890^{* * *}$ & $0.728^{* *}$ & $0.605^{*}$ \\
& $(0.324)$ & $(0.319)$ & $(0.329)$ & $(0.324)$ & $(0.296)$ & $(0.318)$ \\
Soil Suitability (0,1,2) & & $-0.200^{*}$ & $-0.196^{*}$ & & -0.341 & -0.332 \\
& & $(0.112)$ & $(0.114)$ & & $(0.217)$ & $(0.218)$ \\
Median altitude (km) & & -0.090 & -0.104 & & $-0.244^{* * *}$ & $-0.254^{* * *}$ \\
& & $(0.085)$ & $(0.085)$ & & $(0.091)$ & $(0.091)$ \\
1000km to closest mine c.1800 & & 1.489 & 1.301 & & $3.616^{*}$ & $3.326^{*}$ \\
Km to nearest colonial city & & $(1.290)$ & $(1.262)$ & & $(1.900)$ & $(1.809)$ \\
& & -0.000 & 0.000 & & $-0.004^{*}$ & -0.002 \\
Km to Mexico City & & $(0.001)$ & $(0.001)$ & & $(0.002)$ & $(0.002)$ \\
& & 0.001 & 0.001 & & 0.001 & 0.001 \\
Customs Office c.1800 (0,1) & & $(0.001)$ & $(0.001)$ & & $(0.001)$ & $(0.001)$ \\
Alcabala collected (1000s) & & $0.342^{* * *}$ & & & $0.425^{* * *}$ & \\
& & $(0.113)$ & & & $(0.138)$ & \\
\hline Mean dep. var. & & & $0.041^{* * *}$ & & & $0.038^{* * *}$ \\
Municipalities & & & $(0.007)$ & & & $(0.007)$ \\
\hline
\end{tabular}

Note: OLS with state fixed effects and robust standard errors; (3) and (4) include only neighbors.

* sig at 10 percent; ${ }^{* *}$ sig at 5 percent; ${ }^{* *}$ sig at 1 percent.

See the text for a description of the variables and data sources. 


\section{A.2 Alcabala income at the receptoria level}

Table A.3: Public Servants in 1900 and Type of War Dynamic

\begin{tabular}{|c|c|c|c|c|c|c|}
\hline & \multicolumn{6}{|c|}{ Public Servants per 1,000 } \\
\hline & (1) & (2) & $(3)$ & $(4)$ & (5) & (6) \\
\hline Insurgents & $\begin{array}{c}0.155 \\
(0.107)\end{array}$ & $\begin{array}{c}0.047 \\
(0.120)\end{array}$ & $\begin{array}{c}0.113 \\
(0.119)\end{array}$ & $\begin{array}{c}0.170 \\
(0.110)\end{array}$ & $\begin{array}{c}0.017 \\
(0.145)\end{array}$ & $\begin{array}{c}0.087 \\
(0.145)\end{array}$ \\
\hline Local Militias & $\begin{array}{c}0.705^{* *} \\
(0.285)\end{array}$ & $\begin{array}{c}0.617^{* *} \\
(0.263)\end{array}$ & $\begin{array}{c}0.662^{* *} \\
(0.262)\end{array}$ & $\begin{array}{c}0.698^{* *} \\
(0.279)\end{array}$ & $\begin{array}{c}0.595^{* *} \\
(0.249)\end{array}$ & $\begin{array}{c}0.646^{* *} \\
(0.251)\end{array}$ \\
\hline Militia recapture & $\begin{array}{c}0.822^{* * *} \\
(0.219)\end{array}$ & $\begin{array}{c}0.689^{* * *} \\
(0.244)\end{array}$ & $\begin{array}{c}0.778^{* * *} \\
(0.246)\end{array}$ & $\begin{array}{c}0.837^{* * *} \\
(0.222)\end{array}$ & $\begin{array}{c}0.758^{* * *} \\
(0.255)\end{array}$ & $\begin{array}{c}0.870^{* * *} \\
(0.257)\end{array}$ \\
\hline Soil Suitability $(0,1,2)$ & & $\begin{array}{l}-0.107 \\
(0.093)\end{array}$ & $\begin{array}{l}-0.106 \\
(0.095)\end{array}$ & & $\begin{array}{c}-0.195^{* *} \\
(0.089)\end{array}$ & $\begin{array}{c}-0.188^{*} \\
(0.096)\end{array}$ \\
\hline Median altitude (km) & & $\begin{array}{l}-0.097 \\
(0.116)\end{array}$ & $\begin{array}{c}-0.108 \\
(0.118)\end{array}$ & & $\begin{array}{c}-0.195^{*} \\
(0.108)\end{array}$ & $\begin{array}{c}-0.204^{*} \\
(0.107)\end{array}$ \\
\hline $1000 \mathrm{~km}$ to closest mine c. 1800 & & $\begin{array}{l}1.365 \\
(2.338)\end{array}$ & $\begin{array}{c}1.324 \\
(2.284)\end{array}$ & & $\begin{array}{l}5.858^{*} \\
(3.390)\end{array}$ & $\begin{array}{l}5.818^{*} \\
(3.223)\end{array}$ \\
\hline Km to nearest colonial city & & $\begin{array}{l}0.003^{*} \\
(0.002)\end{array}$ & $\begin{array}{l}0.003^{*} \\
(0.002)\end{array}$ & & $\begin{array}{c}0.002 \\
(0.002)\end{array}$ & $\begin{array}{l}0.003^{*} \\
(0.002)\end{array}$ \\
\hline Km to Mexico City & & $\begin{array}{c}0.001 \\
(0.001)\end{array}$ & $\begin{array}{c}0.001 \\
(0.001)\end{array}$ & & $\begin{array}{l}-0.001 \\
(0.002)\end{array}$ & $\begin{array}{l}-0.001 \\
(0.002)\end{array}$ \\
\hline Customs Office c.1800 $(0,1)$ & & $\begin{array}{c}0.401^{* * *} \\
(0.101)\end{array}$ & & & $\begin{array}{c}0.475^{* * *} \\
(0.105)\end{array}$ & \\
\hline Alcabala collected (1000s) & & & $\begin{array}{l}0.007^{* *} \\
(0.003)\end{array}$ & & & $\begin{array}{l}0.008^{* *} \\
(0.003)\end{array}$ \\
\hline Mean dep. var. & 1.138 & 1.138 & 1.138 & 1.198 & 1.198 & 1.198 \\
\hline Municipalities & 2007 & 2007 & 2007 & 1163 & 1163 & 1163 \\
\hline Clusters & 29 & 29 & 29 & 21 & 21 & 21 \\
\hline $\mathrm{R}^{2}$ & 0.234 & 0.263 & 0.262 & 0.159 & 0.213 & 0.210 \\
\hline
\end{tabular}


Table A.4: Municipal Budget in 1910 and Type of War Dynamic

\begin{tabular}{|c|c|c|c|c|c|c|}
\hline & \multicolumn{6}{|c|}{ Municipal Budget per capita 1910} \\
\hline & (1) & $(2)$ & $(3)$ & $(4)$ & $(5)$ & (6) \\
\hline Insurgents & $\begin{array}{c}0.287 \\
(0.173)\end{array}$ & $\begin{array}{l}0.235^{*} \\
(0.131)\end{array}$ & $\begin{array}{l}0.283^{*} \\
(0.164)\end{array}$ & $\begin{array}{c}0.278 \\
(0.170)\end{array}$ & $\begin{array}{l}0.219^{*} \\
(0.120)\end{array}$ & $\begin{array}{c}0.276 \\
(0.169)\end{array}$ \\
\hline Local Militias & $\begin{array}{c}0.473^{* * *} \\
(0.121)\end{array}$ & $\begin{array}{c}0.357^{* * *} \\
(0.118)\end{array}$ & $\begin{array}{c}0.406^{* * *} \\
(0.114)\end{array}$ & $\begin{array}{c}0.458^{* * *} \\
(0.123)\end{array}$ & $\begin{array}{c}0.335^{* *} \\
(0.130)\end{array}$ & $\begin{array}{c}0.404^{* * *} \\
(0.115)\end{array}$ \\
\hline Militia recapture & $\begin{array}{c}0.906^{* * *} \\
(0.283)\end{array}$ & $\begin{array}{c}0.774^{* *} \\
(0.277)\end{array}$ & $\begin{array}{c}0.850^{* *} \\
(0.329)\end{array}$ & $\begin{array}{c}0.890^{* * *} \\
(0.280)\end{array}$ & $\begin{array}{c}0.728^{* * *} \\
(0.242)\end{array}$ & $\begin{array}{c}0.845^{* *} \\
(0.322)\end{array}$ \\
\hline Soil Suitability $(0,1,2)$ & & $\begin{array}{c}-0.200^{*} \\
(0.101)\end{array}$ & $\begin{array}{c}-0.198^{*} \\
(0.109)\end{array}$ & & $\begin{array}{l}-0.341 \\
(0.221)\end{array}$ & $\begin{array}{l}-0.331 \\
(0.225)\end{array}$ \\
\hline Median altitude $(\mathrm{km})$ & & $\begin{array}{l}-0.090 \\
(0.141)\end{array}$ & $\begin{array}{l}-0.099 \\
(0.147)\end{array}$ & & $\begin{array}{l}-0.244 \\
(0.183)\end{array}$ & $\begin{array}{l}-0.257 \\
(0.191)\end{array}$ \\
\hline $1000 \mathrm{~km}$ to closest mine c. 1800 & & $\begin{array}{l}1.489^{*} \\
(0.849)\end{array}$ & $\begin{array}{l}1.394^{*} \\
(0.732)\end{array}$ & & $\begin{array}{c}3.616^{*} \\
(1.869)\end{array}$ & $\begin{array}{l}3.411^{* *} \\
(1.533)\end{array}$ \\
\hline Km to nearest colonial city & & $\begin{array}{l}-0.000 \\
(0.002)\end{array}$ & $\begin{array}{c}0.000 \\
(0.002)\end{array}$ & & $\begin{array}{l}-0.004 \\
(0.004)\end{array}$ & $\begin{array}{l}-0.003 \\
(0.004)\end{array}$ \\
\hline Km to Mexico City & & $\begin{array}{l}0.001^{*} \\
(0.001)\end{array}$ & $\begin{array}{l}0.001^{*} \\
(0.001)\end{array}$ & & $\begin{array}{c}0.001 \\
(0.001)\end{array}$ & $\begin{array}{c}0.001 \\
(0.001)\end{array}$ \\
\hline Customs Office c.1800 $(0,1)$ & & $\begin{array}{c}0.342^{*} \\
(0.174)\end{array}$ & & & $\begin{array}{l}0.425^{*} \\
(0.220)\end{array}$ & \\
\hline Alcabala collected (1000s) & & & $\begin{array}{l}0.006^{*} \\
(0.003)\end{array}$ & & & $\begin{array}{c}0.006^{*} \\
(0.003)\end{array}$ \\
\hline Mean dep. var. & 1.137 & 1.137 & 1.137 & 1.020 & 1.020 & 1.020 \\
\hline Municipalities & 1261 & 1261 & 1261 & 748 & 748 & 748 \\
\hline Clusters & 24 & 24 & 24 & 16 & 16 & 16 \\
\hline $\mathrm{R}^{2}$ & 0.226 & 0.251 & 0.249 & 0.238 & 0.284 & 0.278 \\
\hline
\end{tabular}




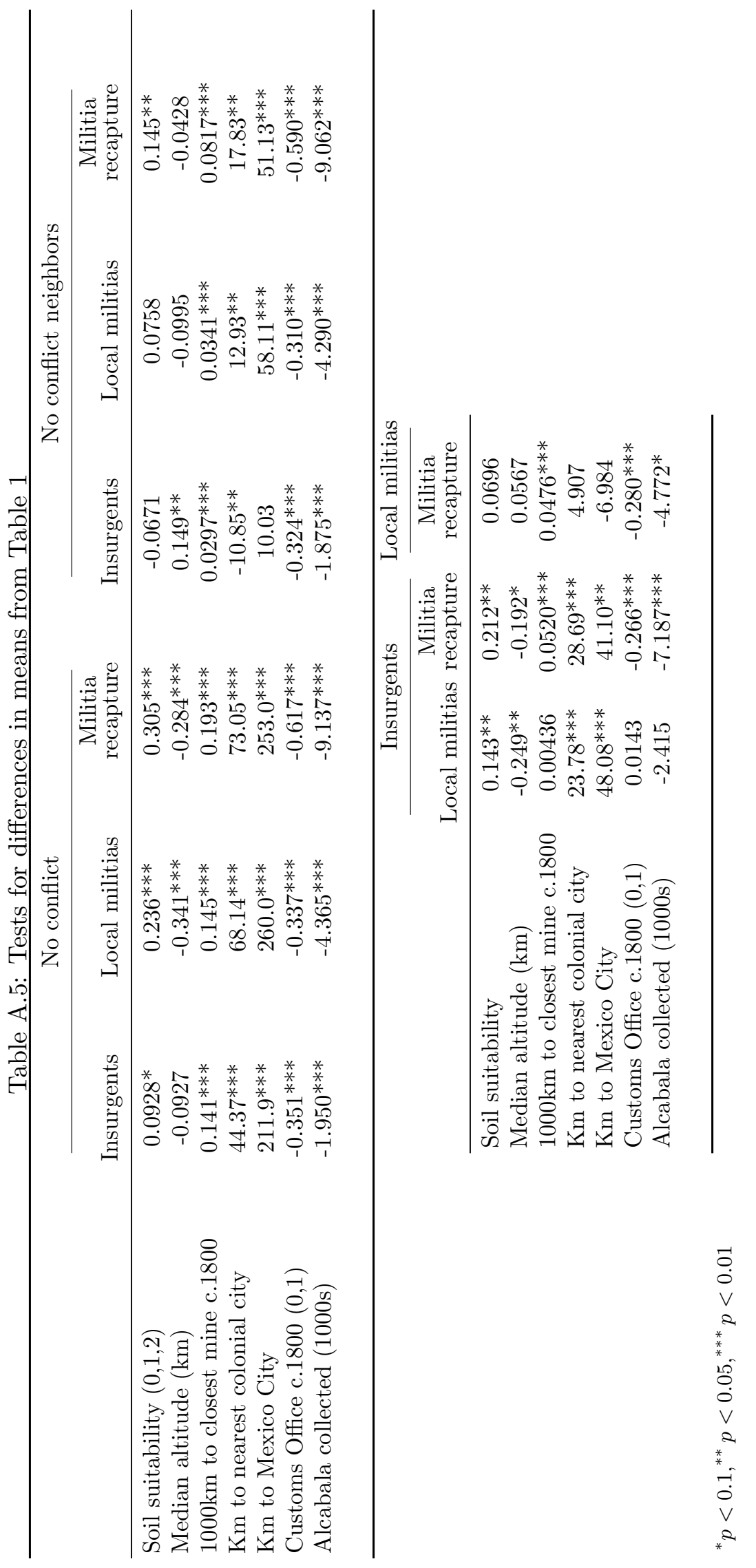




\section{B Cleaning Census data}

The Constitution of 1824 declared Mexico a Federal Republic with 20 states and 3 territories (INEGI 1997). During the 19th century both state boundaries and municipal boundaries changed. The raw 1900 census has 2,773 municipalities, which we match to the 2,456 municipal codes of 2010 as follows.

- The 1900 census has 2,773 municipalities from 29 states. Baja California and Baja California Sur are omitted because in the 1900 data these territories only have state-level data available. Sinaloa was a state but we do not have data for it.

- Of the 2773 municipalities, 53 are duplicate observations in their state and municipality names (24 unique municipal names) but have different values for some variables. We map 5 of the 24 municipal names to separate municipalities in 2010 with similar names, matching the larger municipality in 1900 to the larger municipality in 2010 in terms of population. This leaves 43 observations (19 distinct municipal names) which are duplicates. We add them up assuming they represent observations from the same municipality, which leaves a sample of 2,750 unique municipal observations.

- A preliminary merge is able to match 1,121 of the 2,750 municipalities with 2010 municipal and state names; 1,629 municipalities from 1900 are unmatched, and 1,337 municipalities from 2010 are unmatched (the 2010 data has 2,458 municipalities).

- After cleaning the names of municipalities to match the name they have in 2010 (some are simple spelling changes or typos, while other municipalities changed names completely), 2,683 of the 2,750 municipalities from 1900 are matched with counterparts in 2010 .

- This leaves 67 municipalities which got lost from 1900 to 2010. These "lost" municipalities could be the consequence of municipalities that disappeared all together from 1900 to 2010 , or that we simply could not track.

- This leaves 434 municipalities in 2010 that do not have a counterpart in 1900. These municipalities may be the result of splits from 1900 municipal definitions, municipalities 
that did not exist at all in 1900, or municipalities that did exist in 1900 but that were left out of the census.

- Next, we generate new observations for 1900 to identify municipalities that exist in 2010 but not in 1900 because they split from identifiable 1900-municipalities.

- In doing this, and by removing the states not available in the 1900 census, (39 modern municipalities) we reduce the number of unidentified 2010 municipalities from 440 to 28. Of the 67 unmatched municipalities from 1900, 63 are from Oaxaca, 2 are from Sonora and 2 from Campeche.

- In summary, there are 2,683 municipalities from 1900 matched to 2010: 28 municipalities from 2010 were not matched to historical data, and 67 municipalities from 1900 were not found in the modern data.

- Of the 2,683 municipalities that are matched from 1900, 294 split into 2-4 municipalities by 2010. In these cases, we keep only the 2010 municipality that maintains the same name as in 1900, or in the case that none of the split municipalities share the name, we take the municipality that is larger in 2010 .

- Of these 2,683 municipalities, 997 of them are consolidated into groupings of two or more municipalities by 2010.

- Because of these changes in political divisions, and keeping with the criteria for splits outlined above, the 2,683 municipalities from 1900 represent 2,064 unique municipal codes in 2010 . 


\section{References}

INEGI. 1997. División Territorial de los Estados Unidos Mexicanos de 1810 a 1995. Mexico: Instituto Nacional de Estadística, Geografía e Informática (INEGI). 